\section{Bmi-1 regulates the Ink4a/Arf locus to control pancreatic $\beta$-cell proliferation}

\author{
Sangeeta Dhawan, ${ }^{1}$ Shuen-Ing Tschen, ${ }^{1}$ and \\ Anil Bhushan ${ }^{1,2,3}$
}

${ }^{1}$ Larry L. Hillblom Islet Research Center, Department of Medicine, University of California at Los Angeles, Los Angeles, California 90024, USA; ${ }^{2}$ Molecular Biology Institute, University of California at Los Angeles, Los Angeles, California 90024, USA

The molecular mechanisms that regulate the ageinduced increase of $\mathrm{p} 16^{\mathrm{INK4a}}$ expression associated with decreased $\beta$-cell proliferation and regeneration are not well understood. We report that in aged islets, derepression of the Ink4a/Arf locus is associated with decreased Bmi-1 binding, loss of $\mathrm{H} 2 \mathrm{~A}$ ubiquitylation, increased MLL1 recruitment, and a concomitant increase in H3K4 trimethylation. During $\beta$-cell regeneration these histone modifications are reversed resulting in reduced p16 $^{\text {INK4a }}$ expression and increased proliferation. We suggest that PcG and TrxG proteins impart a combinatorial code of histone modifications on the Ink4a/Arf locus to control $\beta$-cell proliferation during aging and regeneration.

Supplemental material is available at http://www.genesdev.org.

Received September 18, 2008; revised version accepted March 6, 2009.

Emerging evidence indicates that proliferation of pancreatic $\beta$ cells is an important mechanism not only to maintain homeostasis in the endocrine pancreas but also for adapting islet function to changes in metabolic demands (Dor et al. 2004; Kulkarni et al. 2004; Okamoto et al. 2006; Zhong et al. 2007). The inability of the $\beta$ cells to expand and compensate for the changing insulin demand can contribute to the pathogenesis of diabetes. Several studies suggest that $\beta$-cell proliferation declines with age (Teta et al. 2005; Meier et al. 2008) and this age-dependent decline in the $\beta$-cell proliferation could curtail the ability of the endocrine pancreas to respond to metabolic changes. However, the cell-intrinsic genetic and epigenetic mechanisms regulating the age-dependent decline of $\beta$-cell proliferation are not very clear.

The products of the Ink4a/Arf (Cdkn2a) locus, p16 ${ }^{\text {Ink4a }}$ (a negative regulator of CDK4-D-type cyclins) (Kim and Sharpless 2006) and p19 Arf show increased expression with age (Nielsen et al. 1999; Krishnamurthy et al. 2004) and have been linked to reduction in the proliferative capacity of aged $\beta$ cells (Krishnamurthy et al. 2006). Genome-wide studies have linked the Ink4/Arf locus with type 2 diabetes and impaired insulin release, sug-

[Keywords: MLL1; H2A ubiquitylation; aging; diabetes; regeneration] ${ }^{3}$ Corresponding author.

E-MAIL abhushan@mednet.ucla.edu; FAX (310) 206-5368.

Article is online at http://www.genesdev.org/cgi/doi/10.1101/gad.1742609. gesting that failure of islets to expand may play an important role in type 2 diabetes (for review, see Doria et al. 2008). Thus, understanding the regulation of Ink4a/ Arf locus could reveal the molecular basis of reduced $\beta$-cell proliferation with aging and also be extremely useful in devising strategies to foster $\beta$-cell regeneration.

Several genetic studies show that a polycomb group (PcG) protein, Bmi-1, is essential for maintenance of adult stem cell self-renewal primarily due to its ability to repress the Ink4a/Arf locus (Jacobs et al. 1999; Lessard and Sauvageau 2003; Molofsky et al. 2003; Bruggeman et al. 2005). Bmi-1, along with Ring1 and Ring2, is a part of the polycomb-repressive complex 1 (PRC1), which possesses histone H2A-K119 ubiquitin E3 ligase activity, required for the repression of Hox genes (Wang et al. 2004). While Ring2 is the catalytic subunit, Bmi-1 maintains the integrity of the complex and is essential for enzymatic activity (Cao et al. 2005). Analysis in cancer cell lines and embryonic fibroblasts indicates that the ability of Bmi-1 to repress the Ink4a/Arf locus was dependent on the continued presence of another polycomb complex, PRC2, which possesses H3K27 methyltransferase activity mediated by Ezh2, at the Ink4a/Arf locus (Bracken et al. 2007; Kotake et al. 2007). However, the contribution of PRC1-dependent H2A ubiquitylation in the regulation of Ink4a/Arf expression has not been described. In addition, genetic studies show that the axial-skeletal transformations of $B \mathrm{mi}-1^{-1-}$ mice were normalized by the loss of MLL1, a trithorax group (TrxG) protein and an H3K4 methyltransferase, suggesting that both PcG and TrxG proteins act to maintain proper spatial Hox gene expression in mice (Hanson et al. 1999). However, the role of TrxG proteins in regulating the Ink4a/Arf locus is not known.

Here we report that PcG and TrxG complexes play opposing roles in controlling the Ink4a/Arf locus to regulate the proliferative capacity of $\beta$ cells during aging and regeneration. We show that decreased Bmi-1 binding to the Ink4a/Arf locus in aged islet led to reduced $\mathrm{H} 2 \mathrm{~A}$ ubiquitylation, which stimulated the recruitment of MLL1 and increased H3K4 trimethylation that augmented transcriptional activity from the Ink $4 a /$ Arf locus. During $\beta$-cell regeneration, increased Bmi- 1 binding coincided with decreased $\mathrm{H} 3 \mathrm{~K} 4$ trimethylation, resulting in repression of the Ink4a/Arf locus and augmented $\beta$-cell proliferation. These results support the view that PcG and TrxG protein-dependent regulation of the Ink4a/Arf locus plays a critical role in regulating pancreatic $\beta$-cell proliferation during aging and regeneration.

\section{Results and Discussion}

To establish the compartment and age-dependent changes in the expression of Bmi-1, we analyzed the expression pattern of Bmi-1 in mouse pancreata at different ages. Immunohistochemical analysis on pancreatic sections from 2-wk-old mice revealed strong nuclear staining for Bmi-1 in the islets and ductal structures. Costaining with insulin showed that Bmi-1 was expressed primarily in $\beta$ cells in the islets (Fig. 1A). Immunostaining of pancreatic sections from different ages showed that the expression of Bmi-1 in the islets and ducts declined with age, and in 10 -wk-old pancreas, only a few $\beta$ cells showed weak 
A

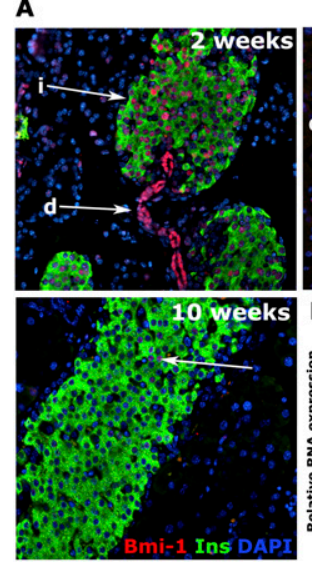

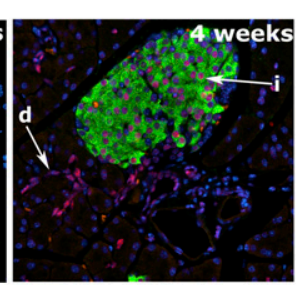

B ,

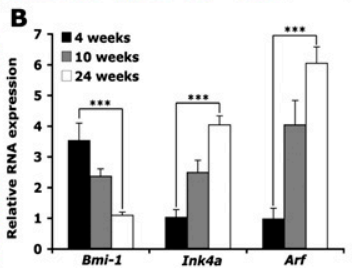

C

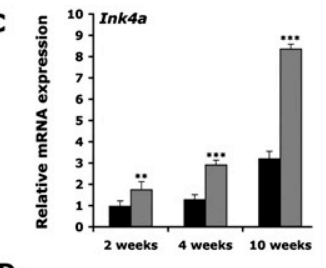

D

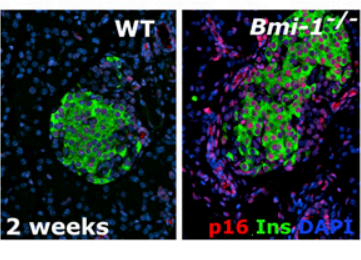

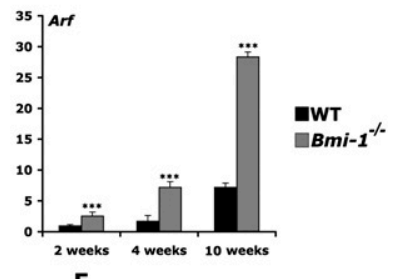

E

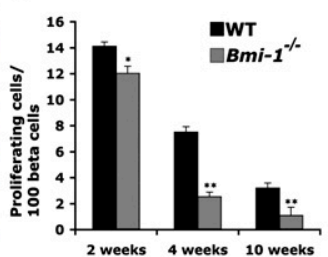

Figure 1. The expression of Bmi-1 declined with age and correlated with increased expression of Ink4a/Arf genes and reduced $\beta$-cell proliferation. (A) Expression pattern of Bmi-1 in the representative pancreatic sections from wild-type mice aged 2, 4, and 10 wk, respectively (20× magnification). (i) Islet cells; (d) ductal cells. (B) RNA levels of Bmi-1, Ink4a, and Arf in islets isolated from mice at different ages. (C) RNA levels of Ink $4 a$ and Arf and $(D)$ Immunofluorescence for p16 and insulin, with DAPI, in pancreatic sections from 2-wk-old wild-type (WT) and $B m i-1^{-/-}$mice (20× magnification). (E) Quantification of proliferating $\beta$ cells at 2, 4, and 10 wk in wild-type and Bmi-1 ${ }^{-/}$mice, as a percentage of Ki67 ${ }^{+}$insulin double-positive cells in islets. $\left(^{\star}\right) P<0.05 ;\left(^{\star \star}\right) P<0.01 ;\left(^{\star \star \star}\right) P<0.005$.

staining (Fig. 1A). This age-related decline in the levels of Bmi-1 was reflective of the changes in the transcript levels of Bmi-1 and correlated with a concomitant increase in the levels of transcripts from the Ink4a/Arf locus (Fig. 1B). This sharp decline in Bmi-1 expression early after birth may be unique to pancreatic $\beta$ cells as previous reports indicate constant levels of Bmi-1 with respect to age (Krishnamurthy et al. 2004; Janzen et al. 2006; Molofsky et al. 2006; Bracken et al. 2007).

We next examined whether Bmi-1 regulated the expression of the Ink4a/Arf locus in pancreatic islets by analyzing $B m i-1^{-1-}$ mice (van der Lugt et al. 1994). Quantitative RT-PCR revealed increased transcript levels of Ink $4 a$ and Arf in islets isolated from Bmi-1 ${ }^{-1-}$ mice compared with the wild-type littermates (Fig. 1C). Immunohistochemistry of pancreatic sections demonstrated strong expression of $\mathrm{p} 16^{\text {Ink4a }}$ levels in the islets from 2 -wk-old $B m i-1^{-1-}$ mice, while hardly any p16 $6^{\text {Ink4a }}$ expression was discernable in the pancreas of wild-type littermates (Fig. 1D). The up-regulation of $\mathrm{p} 16^{\text {Ink4a }}$ and p19 ${ }^{\text {Arf }}$ proteins in Bmi-1 $1^{-/-}$mice was also confirmed by immunoblots (Supplemental Fig. S1A). However, other cell cycle regulators examined were unaffected in islets from Bmi-1 $1^{-9-}$ mice (Supplemental Fig. S1B). Analysis of $\beta$-cell proliferation by staining pancreatic sections with Ki67 and insulin showed that the percentage of proliferating $\beta$ cells was greatly reduced in $B \mathrm{mi}-1^{-f_{-}}$mice compared with the wild-type littermates from 2 wk after birth (Fig. 1E), and confirmed by BrdU incorporation studies (Supplemental Fig. S1C). No difference in the percentage of proliferating exocrine cells between the $B \mathrm{mi}-1^{-/-}$mice and wild-type littermates was found (Supplemental Fig. S1D), indicating that there was no generalized decrease in proliferation throughout the pancreas. These observations suggested that loss of Bmi-1 resulted in reduced $\beta$-cell proliferation due to the premature up-regulation of $\mathrm{p} 16^{\text {Ink } 4 \mathrm{a}}$.

To assess whether increased levels of $\mathrm{p} 16^{\mathrm{Ink} 4 \mathrm{a}}$ were responsible for the reduced proliferative capacity of pancreatic $\beta$ cells in $B m i-1^{-/-}$mice, isolated islets were treated with siRNA targeting Ink4a. Islets isolated from
Bmi-1 $1^{-/-}$mice displayed reduced proliferation compared with islets isolated from wild-type littermates. Strikingly, treatment with Ink $4 a$ siRNA, which effectively reduced Ink $4 a$ expression, was sufficient to rescue $\beta$-cell proliferation in Bmi-1 $1^{-/-}$islets (Fig. 2A). Similarly, knockdown of Bmi-1 in the pancreatic $\beta$-cell line Min 6 resulted in decreased cell growth kinetics that were rescued by the simultaneous knockdown of both Bmi-1 and Ink $4 a$ (Fig. 2B). These data indicate that repression of $\mathrm{p} 16^{\text {Ink4a }}$ is the major mechanism by which Bmi-1 regulates $\beta$-cell proliferation. We next assessed the physiological consequences of loss of Bmi-1 by carrying out morphometric and metabolic analyses of $B m i-1^{-P}$ mice. Examination of pancreatic sections from 10 -wk-old mice revealed a dramatic reduction in the size of islets in the pancreas from $B \mathrm{mi}^{-} \mathrm{1}^{-/-}$mice as compared with their littermates (Fig. $2 C)$. The size of individual $\beta$ cells did not appear to differ in the $\mathrm{Bmi-1}-\mathrm{1}^{-1-}$ and wild-type littermates, indicating that the reduced islet size was likely due to a decrease in the number of $\beta$ cells. The $\beta$-cell mass in $B m i-1^{-/-}$mice was similar to wild-type littermates at birth (Supplemental Fig. S2A,B) but was severely reduced by $10 \mathrm{wk}$ (Fig. 2D), suggesting a postnatal role for Bmi-1 in $\beta$-cell proliferation. The reduced $\beta$-cell mass in the $B m i-1^{-/-}$mice resulted in abnormal glucose homeostasis, as measured by glucose tolerance tests (GTTs) at $10 \mathrm{wk}$ (Fig. 2E). Wildtype mice had the highest glucose levels 15 min after injection and reached baseline by the end of the 120-min testing period. In contrast, $B m i-1^{-1-}$ mice displayed elevated blood glucose levels that failed to return to baseline levels during the testing period. The serum insulin levels after overnight fasting failed to increase in $B \mathrm{mi}^{-} \mathrm{1}^{-/-}$mice in response to glucose challenge (Fig. $2 \mathrm{~F}$ ). Insulin tolerance test showed no difference between $\mathrm{Bmi}$ $1^{-/-}$and wild-type littermates, indicating that changes in islet physiology in the $\mathrm{Bmi}-1^{-/-}$mice were not due to effects of insulin resistance (Supplemental Fig. S2C).

To understand the mechanism by which Bmi-1 regulates the Ink4a/Arf locus in $\beta$ cells, we first examined the binding of Bmi-1 across the entire Ink4a/Arf locus by chromatin immunoprecipitation (ChIP) assays (Fig. 3A). 
Dhawan et al.
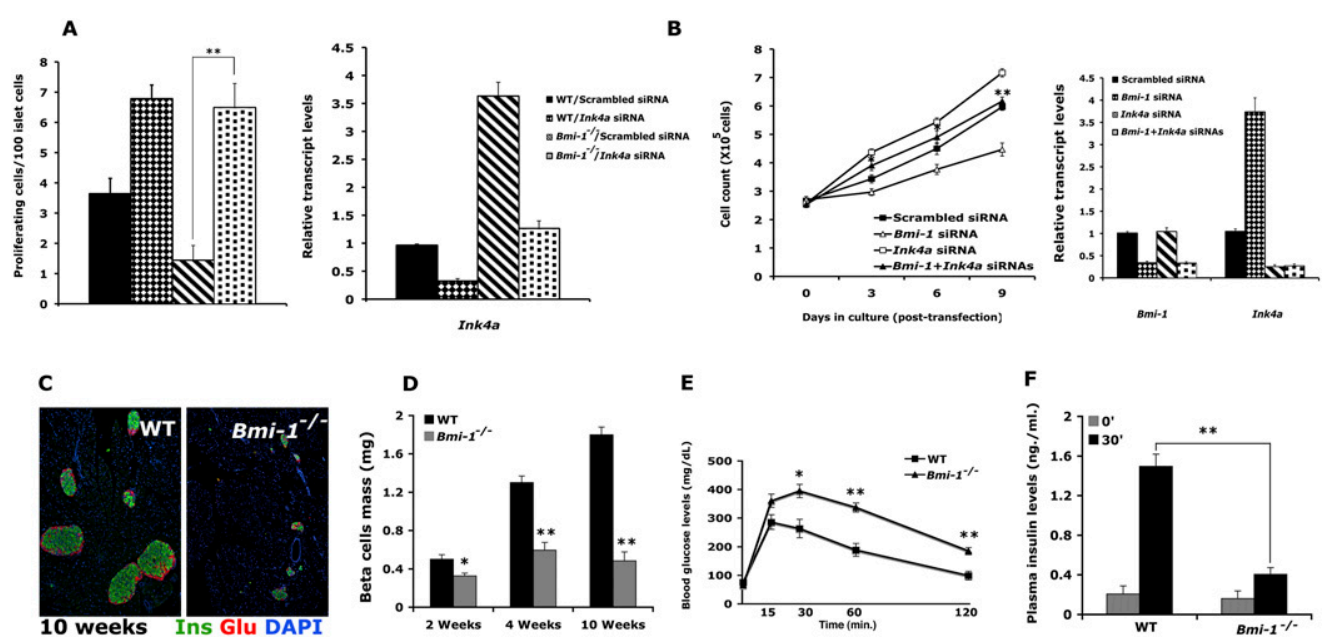

Figure 2. $B m i-1^{-1-}$ mice display diminished $\beta$-cell mass, hypoinsulinemia, and glucose intolerance. $(A)$ Quantification of proliferating islet cells (left panel) and levels of Ink4a (right panel) in cultured islets isolated from 4-wk-old wild-type (WT) and Bmi-1 ${ }^{-1-}$ mice, transfected with Ink $4 a$ or scrambled siRNAs. (B) Growth profiles (left panel) and corresponding levels of Bmi-1 and Ink4a (right panel) in Min6 cells transfected with Bmi-1, Ink4a, Bmi-1 + Ink4a, or scrambled siRNAs. P-value symbols indicated are for comparison of Bmi-1 and Bmi-1+Ink4a samples. $(C)$ Pancreatic sections from 10-wk-old wild-type and Bmi-1 ${ }^{-/-}$mice stained with insulin (Ins) and glucagon (Glu) with DAPI (5× magnification). (D) $\beta$-Cell mass in wild-type and Bmi-1 ${ }^{-1-}$ mice at 2,4 , and $10 \mathrm{wk}$ of age $\left(n=5\right.$ for each phenotype and age). (E) GTT for wild-type and $B \mathrm{mi}-1^{-/-}$mice at $10 \mathrm{wk}\left(\mathrm{n}=5\right.$ for each phenotype). (F) Plasma insulin levels in 10 -wk-old wild-type and Bmi-1 ${ }^{-/-}$mice (fasted overnight) at 0 and $30 \mathrm{~min}$, after glucose injection $\left(n=5\right.$ for each phenotype). $\left(^{\star}\right) P<0.05$; $\left.\left.^{\star \star}\right) P<0.01{ }^{\left({ }^{\star \star}\right)}\right) P<0.005$.

ChIP assays demonstrated the binding of Bmi-1 throughout the Ink4a/Arf locus in the islets from 4-wk-old wild-type mice, with age-matched $\mathrm{Bmil}^{-/-}$islets serving as binding controls (Fig. 3B). We next assessed whether loss of Bmi-1 in islets resulted in changes in polycombdependent histone modifications on the Ink4a/Arf locus. Besides analyzing the levels of H2A ubiquitylation (H2A$\mathrm{ub}$, we also examined the levels of trimethylation at H3K27 (H3K27me3), a histone modification mediated by Ezh2 that has been linked with silencing of the Ink4a/Arf locus (Bracken et al. 2007; Kotake et al. 2007). Islets from $\mathrm{Bmi1}^{-/-}$mice showed a significant decrease in H2A ubiquitylation levels (Fig. 3B). Surprisingly, however, the levels of $\mathrm{H} 3 \mathrm{~K} 27 \mathrm{me} 3$ at Ink4a/Arf locus were unaffected (Fig. 3B). Further, the binding and levels of Ezh2 were unchanged in the absence of Bmi-1, suggesting that the Ezh2-dependent H3K27me3-repressive histone modification mark alone was not sufficient for repression of the Ink4a/Arf locus (Fig. 3B; Supplemental Fig S3A). To address how the Ezh2-mediated methylation of H3K27 contributed to the regulation of the Ink4a/Arf locus, we examined islets in which Ezh2 expression was knocked down by specific siRNA (Supplemental Fig. S3B). The knockdown of $E z h 2$ not only led to reduced binding of Ezh2 and trimethylation of H3K27, but Bmi-1 binding as well as H2A ubiquitylation levels were also reduced at the Ink4a/Arf locus (Fig. 3C), suggesting that Ezh2 is required for the binding of Bmi-1. These data are consistent with a sequential recruitment mechanism of polycomb action (Hernandez-Munoz et al. 2005) to regulate the Ink4a/Arf locus, in which Ezh2-mediated H3K27 methylation enables the binding of Bmi-1, leading to $\mathrm{H} 2 \mathrm{~A}$ ubiquitylation and repression of the Ink4a/Arf locus.
As aging islets are also characterized by increased p16 ${ }^{\text {Ink4a }}$ expression (Supplemental Fig. S4A,B), we compared the binding of Bmi-1 and Ezh2 and histone modifications within the Ink4a/Arf locus in young $(2$ wk) and old (24 wk) islets. The binding of both Bmi-1 and Ezh2 at the Ink4a/Arf locus declined in the old islets and resulted in reduced levels of $\mathrm{H} 3-\mathrm{K} 27 \mathrm{me} 3$ and $\mathrm{H} 2 \mathrm{~A}-\mathrm{ub}$ modifications at the Ink4a/Arf locus (Fig. 4A). The fact that the expression from Ink4a/Arf locus increased with aging even in the absence of Bmi-1 (as shown in Fig. 1C) suggested additional levels of regulation of the Ink4a/Arf
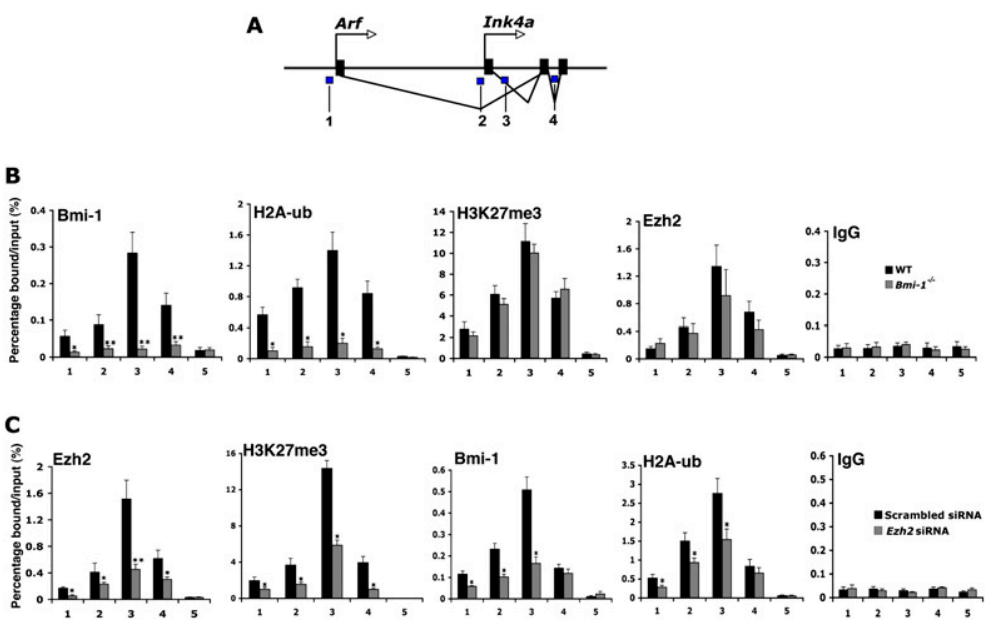

Figure 3. Bmi-1 plays a key role in regulation of the Ink4a/Arf locus through modulation of histone modifications. (A) Schematic representation of the Ink $4 a / A r f$ locus, with blue regions marked 1-4 indicating the amplified regions in the ChIP studies. ChIP analysis for the indicated antibodies at the Ink4a/Arf locus in islets isolated from wild-type (WT) and $B m i-1^{-/-}$mice (4 wk old) $(B)$ and upon treatment of islets from 4-wk-old mice $(C)$, with siRNA targeting Ezh2 or control, scrambled siRNA. Primer set 5 indicates negative control (Exon 2 of HoxC13 locus) (Cao et al.

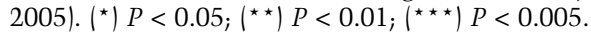


locus. We examined whether other histone modifications typically associated with transcriptional activation were changed in aged islets. We compared the status of H3K4 trimethylation $(\mathrm{H} 3 \mathrm{~K} 4 \mathrm{me} 3)$ at the Ink4a/Arf locus in young and old islets and found increased levels of H3K4 trimethylation in the old islets (Fig. 4A). These changes in $\mathrm{H} 3 \mathrm{~K} 4$ trimethylation prompted us to compare the binding of H3K4 methyltransferase MLL1 to Ink4a/Arf locus in young and old islets. We found that the increased levels of $\mathrm{H} 3 \mathrm{~K} 4 \mathrm{me} 3$ at the Ink4a/Arf locus with islet aging coincided with increased binding of MLL1 (Fig. 4A). These results suggested that polycomb and MLL1 have opposing roles in the regulation of the Ink4a/Arf locus and that the loss of Bmi-1 could initiate mechanisms that enhance transcriptional activation from the Ink4a/Arf locus. To test this, we compared the levels of MLL1 binding and $\mathrm{H} 3 \mathrm{~K} 4$ trimethylation modifications at the Ink4a/Arf locus in the wild-type and $B m i-1^{-1-}$ islets. In the absence of Bmi-1, we found increased binding of MLL1 and increased levels of H3K4me3 modification at the Ink4a/Arf locus (Supplemental Fig. S4C). Our observations suggest that in the young islets, high levels of Bmi-1 would ensure increased H2A-ubiquitylation (Fig. 4B), repression of Ink4a/Arf expression and greater $\beta$-cell proliferative capacity. With aging, reduced Bmi-1 binding would facilitate $\mathrm{H} 3 \mathrm{~K} 4$ trimethylation, increased Ink4a/ Arf expression, and reduced $\beta$-cell proliferative capacity.

To study the role of $B m i-1$ in regulating the regenerative capacity of $\beta$ cells, we used a model of islet regeneration after streptozotocin (STZ)-induced $\beta$-cell destruction. Four-week-old mice were subjected to a single dose of STZ $(90 \mathrm{mg} / \mathrm{kg})$, and pancreata were harvested at different time points. This low-dose treatment did not lead to any significant DNA damage and islet morphology was maintained (Supplemental Fig. S5A). Increased $\beta$-cell proliferation was observed after STZ treatment, consistent with regeneration following $\beta$-cell destruction (Supplemental Fig. S5B). Immunoblots of islets isolated after $4 \mathrm{~d}$ of STZ treatment showed increased Bmi-1 and decreased p16 ${ }^{\text {Ink4a }}$ levels (Supplemental Fig. S5C). Immunohistochemistry revealed that STZ treatment resulted in increased number of Bmi-1-expressing $\beta$ cells that often coincided with proliferating islet cells (Fig. 5A; Supplemental Fig. S5D). Increased Bmi-1 expression was consistent with increased ubiquitylated $\mathrm{H} 2 \mathrm{~A}$ and reduced levels of p16 $6^{\text {Ink4a }}$ in the $\beta$ cells (Fig. 5 B,C). The lower levels of $\mathrm{p} 16^{\text {Ink4a }}$ were sustained $15 \mathrm{~d}$ after the treatment (Supplemental Fig. S5E). ChIP analysis on isolated islets showed that up-regulation of Bmi-1 levels correlated with increased Bmi-1 binding, H2A ubiquitylation, and a concomitant decrease in H3K4 trimethylation at the Ink4a/ Arf locus, upon STZ treatment (Fig. 5D). These results indicate that during regeneration increased Bmi-1 binding to the Ink $4 a / A r f$ locus led to a decrease in p $16^{\text {Ink } 4 \text { a }}$ levels, resulting in increased proliferation of $\beta$ cells. To confirm the requirement of Bmi-1 for $\beta$-cell proliferation during regeneration, $B m i-1^{-1-}$ mice and wild-type littermates were subjected to STZ treatment. $B m i-1^{-1-}$ mice after STZ treatment did not show any changes in $\beta$-cell proliferation (Fig. 5E). These results suggest a strong link between Bmi-1-dependent H2A ubiquitylation of Ink4a/ Arf locus and $\beta$-cell regenerative capacity. While the Ink4a/Arf locus is clearly regulated in a Bmi-1-dependent fashion during $\beta$-cell regeneration, the global appearance of changes in $\mathrm{H} 2 \mathrm{~A}$ ubiquitylation with aging and/or regeneration may be indicative of the existence of other potential chromatin targets for the polycomb complexes in the $\beta$ cells. Our studies, along with recent observations in liver regeneration models, suggest that H2A ubiquitylation may be a key phenomenon governing gene silencing during tissue regeneration (Nakagawa et al. 2008).

Even though Bmi-1 has been widely implicated in the regulation of Ink4a/Arf locus, the precise molecular mechanisms have not been reported previously. We show here that Bmi-1 is critical for the H2A ubiquitylation and repression of the Ink4a/Arf locus. Loss of H2A ubiquitylation promotes MLL-mediated $\mathrm{H} 3 \mathrm{~K} 4$ trimethylation and transcriptional activation from the Ink4a/Arf locus. While a role for Bmi-1 in promoting self-renewal of stem cells and regulation of senescence via repression of p16 ${ }^{\text {Ink4a }}$ has been described previously, our study shows that self-renewal and regeneration of pancreatic $\beta$ cells, a terminally differentiated cell type, are also governed by Bmi-1-dependent regulation of the Ink4a/Arf locus.

Our work suggests that levels of Bmi-1 are critical in determining the proliferative potential of $\beta$ cells. A decline in the levels and binding of Bmi-1 to Ink4a/Arf locus with aging translates into reduced proliferative potential and consequently reduced selfrenewal of $\beta$ cells. Experiments with STZ-induced $\beta$-cell regeneration suggest that the modulation of Ink4a/Arf expression levels by Bmi-1 is critical to the $\beta$ cell regeneration process. It will be interesting to examine if similar changes in the levels of Bmi-1 and histone modifications of the Ink4a/Arf are a prerequisite for $\beta$-cell mass expansion in physiological contexts, such as dietary stress and obesity. Our study shows a requirement for polycomb proteins in the regulation of pancreatic $\beta$-cell self-renewal via Ink4a/Arf locus with aging. However, our work does not rule out the involvement of other targets of PcG and/or TrxG in $\beta$-cell aging. In this context, it is noteworthy that rescue of $\beta$-cell proliferation by inactivation of $\mathrm{p} 16^{\text {Ink4a }}$ in the Bmi-1 ${ }^{-1}$ islets and Ezh2 $\beta$-cell knockout mice (H. Chen and S.K. Kim, pers.
Figure 4. Polycomb-mediated regulation of Ink4a/Arf locus during aging by histone modification $(A)$ ChIP analysis for the indicated antibodies at the Ink4a/Arf locus with aging, with IgG as control, Young indicates $2 \mathrm{wk}$; old, 24-30 wk of age. Time points chosen to reflect very high $(2 \mathrm{wk})$ and low $(24-30 \mathrm{wk})$ levels of $\mathrm{PcG}$ proteins. $(B)$ Coimmunostaining of ubiquitinated H2A (H2A-ub) and insulin (Ins) with DAPI, in pancreatic sections from 2 wk-old and 24-wk-old wild-type mice. $\left(^{\star}\right) P<0.05 ;\left(^{\star \star}\right) P<0.01 ;\left(^{\star \star \star}\right) P<0.005$. 
Dhawan et al.
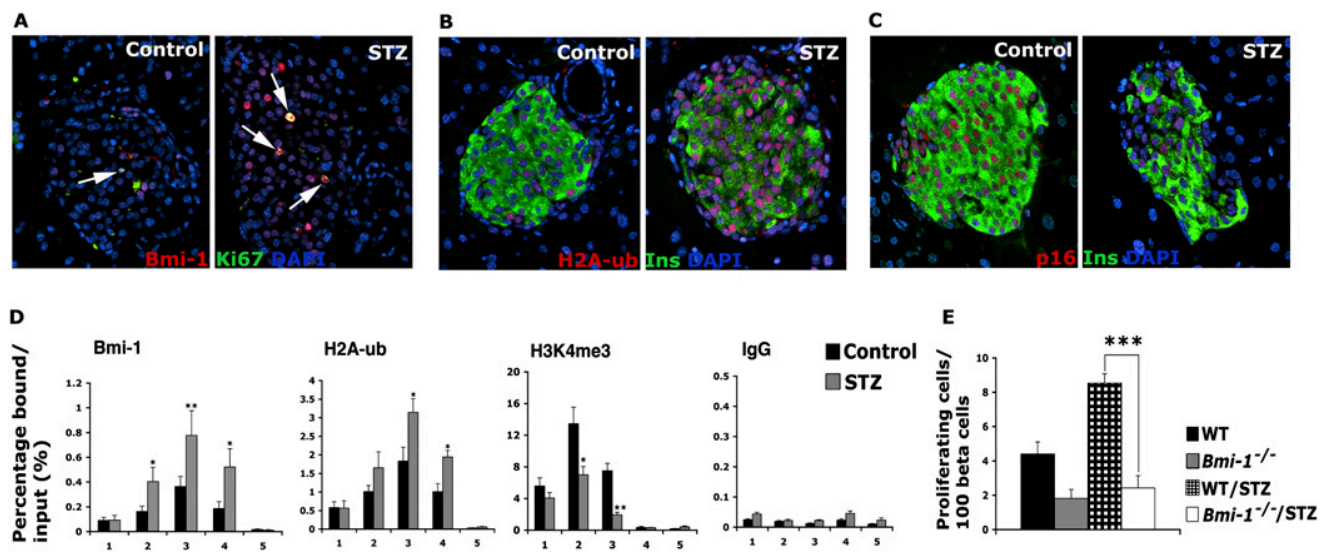

Figure 5. Bmi-1-dependent regulation of Ink4a/Arf locus plays a critical role in $\beta$-cell regeneration. Coimmunostaining for Bmi-1 and Ki67 $(A)$ and coimmunostaining for H2A-ub and insulin (Ins) with DAPI $(B)$ in pancreatic section from vehicle or STZ-treated 4-wk-old wild-type (WT) mice. Arrows indicate cells that are positive for both Bmi-1 and Ki67 (20× magnification). (C) Immunofluorescence for p16 ${ }^{\text {Ink4a }}$ and insulin (Ins) with DAPI on pancreatic sections from 4-wk-old mice treated with control vehicle or a single dose of STZ $(20 \times$ magnification). (D) ChIP analysis for the indicated antibodies at the Ink4a/Arf locus on islets from 4-wk-old wild-type mice injected with STZ or control vehicle. Analyses $A-D$ were performed on mice $4 \mathrm{~d}$ after injections. $(E)$ Proliferation of $\beta$ cells in wild-type and Bmi-1 ${ }^{-1-}$ mice after STZ or vehicle treatment, measured as a percentage of $\mathrm{Ki}_{6} 7^{+}$insulin double-positive islet cells. Analysis performed $15 \mathrm{~d}$ after STZ or control injections. $n=5$ mice per treatment. ${ }^{\star}$ ) $P<0.05 ;\left(^{\star \star}\right) P<0.01 ;\left(^{\star \star \star}\right) P<0.005$.

comm.) indicates that Ink4a/Arf might be the primary PcG target in maintenance of $\beta$-cell proliferative potential.

Although we focused on pancreatic $\beta$ cells, the regulation of the Ink4a/Arf locus by PcG and TrxG proteins is likely to be a general mechanism utilized by other cell types. Moreover, our data also provide a molecular basis for the previously reported genetic antagonism between PcG and TrxG regulatory modules (Hanson et al. 1999). Finally, our results suggest that the epigenetic "histone code" in pancreatic $\beta$ cells is dynamic and that reprogramming of the $\beta$-cell epigenome by members of the polycomb gene family could be an effective strategy in promoting $\beta$-cell regeneration in diabetes.

\section{Materials and methods}

Animals, islets and cell lines, and metabolic and regeneration analyses

Targeted disruption of the Bmi-1 allele has been described before (van der Lugt et al. 1994). The animals were maintained by mating Bmi-1 ${ }^{+/-}$males and females on a C57BL/6J background. Min6 cells were maintained in DMEM containing $10 \%$ FBS and $25 \mathrm{mM}$ glucose at $37^{\circ} \mathrm{C}$ in $5 \% \mathrm{CO}_{2}$ environment. Islets were isolated using the Liberase enzyme blend (Roche), and cultured as described before (Zhong et al. 2007). GTT and plasma insulin measurements were performed following overnight fasting of mice, as described previously (Zhong et al. 2007). Four-week-old $\mathrm{Bmi-1^{-1- }}$ mice and wild-type littermates were given single intraperitoneal injection of $90 \mathrm{mg} / \mathrm{kg} \mathrm{STZ}$ (Sigma-Aldrich) or vehicle, and the pancreata were harvested.

\section{Histology and morphometry}

Standard immunofluorescence staining protocol was used (Zhong et al. 2007). Details of the antibodies, proliferation, and morphometric analyses are described in the Supplemental Material.

\section{Gene expression (targeting and analysis) and ChIP}

RNA and Western blot analyses were performed according to the Supplemental Material. The knockdown of Ezh2, Bmi-1, and Ink $4 a$ in Min 6 cells or mouse islets was done by transfection with a specific targeting siRNA listed in the Supplemental Material. ChIP analysis was performed using the Millipore ChIP kit (Millipore 17-295) according to the manufacturer's instructions with minor modifications. RT-PCR and ChIP primers are listed in Supplemental Tables 1 and 2, respectively.

Detailed experimental procedures are described in the Supplemental Material.

\section{Acknowledgments}

We are grateful to Maarten van Lohuizen for the $B m i-1^{-1-}$ mice and Seung Kim for communicating unpublished observations. We thank Senta Georgia for her advice in the laboratory and Lendy Le, Rosemary Soliz, and Murtaza Kanji for excellent technical help. This work was supported by grants from NIH DK-068763 and DK-80996, Larry L. Hillblom Foundation, and Juvenile Diabetes Research Foundation to A.B.

\section{References}

Bracken, A.P., Kleine-Kohlbrecher, D., Dietrich, N., Pasini, D., Gargiulo, G., Beekman, C., Theilgaard-Monch, K., Minucci, S., Porse, B.T., Marine, J.C., et al. 2007. The Polycomb group proteins bind throughout the INK4A-ARF locus and are disassociated in senescent cells. Genes \& Dev. 21: 525-530.

Bruggeman, S.W., Valk-Lingbeek, M.E., van der Stoop, P.P., Jacobs, J.J., Kieboom, K., Tanger, E., Hulsman, D., Leung, C., Arsenijevic, Y., Marino, S., et al. 2005. Ink4a and Arf differentially affect cell proliferation and neural stem cell self-renewal in Bmil-deficient mice. Genes \& Dev. 19: 1438-1443.

Cao, R., Tsukada, Y., and Zhang, Y. 2005. Role of Bmi-1 and RinglA in H2A ubiquitylation and Hox gene silencing. Mol. Cell 20: 845854.

Dor, Y., Brown, J., Martinez, O.I., and Melton, D.A. 2004. Adult pancreatic $\beta$-cells are formed by self-duplication rather than stemcell differentiation. Nature 429: 41-46. 
Doria, A., Patti, M.E., and Kahn, C.R. 2008. The emerging genetic architecture of type 2 diabetes. Cell Metab. 8: 186-200.

Hanson, R.D., Hess, J.L., Yu, B.D., Ernst, P., van Lohuizen, M., Berns, A., van der Lugt, N.M., Shashikant, C.S., Ruddle, F.H., Seto, M., et al. 1999. Mammalian Trithorax and polycomb-group homologues are antagonistic regulators of homeotic development. Proc. Natl. Acad. Sci. 96: 14372-14377.

Hernandez-Munoz, I., Taghavi, P., Kuijl, C., Neefjes, J., and van Lohuizen, M. 2005. Association of BMIl with polycomb bodies is dynamic and requires PRC2/EZH2 and the maintenance DNA methyltransferase DNMT1. Mol. Cell. Biol. 25: 11047-11058.

Jacobs, J.J., Kieboom, K., Marino, S., DePinho, R.A., and van Lohuizen, M. 1999. The oncogene and Polycomb-group gene bmi-1 regulates cell proliferation and senescence through the ink4a locus. Nature 397: 164-168.

Janzen, V., Forkert, R., Fleming, H.E., Saito, Y., Waring, M.T., Dombkowski, D.M., Cheng, T., DePinho, R.A., Sharpless, N.E., and Scadden, D.T. 2006. Stem-cell ageing modified by the cyclin-dependent kinase inhibitor p16INK4a. Nature 443: 421-426.

Kim, W.Y. and Sharpless, N.E. 2006. The regulation of INK4/ARF in cancer and aging. Cell 127: 265-275.

Kotake, Y., Cao, R., Viatour, P., Sage, J., Zhang, Y., and Xiong, Y. 2007. pRB family proteins are required for H3K27 trimethylation and Polycomb repression complexes binding to and silencing p16INK $4 \alpha$ tumor suppressor gene. Genes \& Dev. 21: 49-54.

Krishnamurthy, J., Torrice, C., Ramsey, M.R., Kovalev, G.I., Al-Regaiey, K., Su, L., and Sharpless, N.E. 2004. Ink4a/Arf expression is a biomarker of aging. J. Clin. Invest. 114: 1299-1307.

Krishnamurthy, J., Ramsey, M.R., Ligon, K.L., Torrice, C., Koh, A., Bonner-Weir, S., and Sharpless, N.E. 2006. p16INK4a induces an age-dependent decline in islet regenerative potential. Nature 443: 453-457.

Kulkarni, R.N., Jhala, U.S., Winnay, J.N., Krajewski, S., Montminy, M., and Kahn, C.R. 2004. PDX-1 haploinsufficiency limits the compensatory islet hyperplasia that occurs in response to insulin resistance. J. Clin. Invest. 114: 828-836.

Lessard, J. and Sauvageau, G. 2003. Bmi-1 determines the proliferative capacity of normal and leukaemic stem cells. Nature 423: 255-260.

Meier, J.J., Butler, A.E., Saisho, Y., Monchamp, T., Galasso, R., Bhushan, A., Rizza, R.A., and Butler, P.C. 2008. $\beta$-Cell replication is the primary mechanism subserving the postnatal expansion of $\beta$-cell mass in humans. Diabetes 57: 1584-1594.

Molofsky, A.V., Pardal, R., Iwashita, T., Park, I.K., Clarke, M.F., and Morrison, S.J. 2003. Bmi-1 dependence distinguishes neural stem cell self-renewal from progenitor proliferation. Nature 425: 962-967.

Molofsky, A.V., Slutsky, S.G., Joseph, N.M., He, S., Pardal, R., Krishnamurthy, J., Sharpless, N.E., and Morrison, S.J. 2006. Increasing p16INK4a expression decreases forebrain progenitors and neurogenesis during ageing. Nature 443: 448-452.

Nakagawa, T., Kaiitani, T., Togo, S., Masuko, N., Ohdan, H., Hishikawa, Y., Koji, T., Matsuyama, T., Ikura, T., Muramatsu, M., et al. 2008. Deubiquitylation of histone $\mathrm{H} 2 \mathrm{~A}$ activates transcriptional initiation via trans-histone cross-talk with H3K4 di- and trimethylation. Genes \& Dev. 22: 37-49.

Nielsen, G.P., Stemmer-Rachamimov, A.O., Shaw, J., Roy, J.E., Koh, J., and Louis, D.N. 1999. Immunohistochemical survey of p16INK4A expression in normal human adult and infant tissues. Lab. Invest. 79: 1137-1143.

Okamoto, H., Hribal, M.L., Lin, H.V., Bennett, W.R., Ward, A., and Accili, D. 2006. Role of the forkhead protein FoxO1 in $\beta$ cell compensation to insulin resistance. J. Clin. Invest. 116: 775-782.

Teta, M., Long, S.Y., Wartschow, L.M., Rankin, M.M., and Kushner, J.A. 2005. Very slow turnover of $\beta$-cells in aged adult mice. Diabetes 54: 2557-2567.

van der Lugt, N.M., Domen, J., Linders, K., van Roon, M., RobanusMaandag, E., te Riele, H., van der Valk, M., Deschamps, J., Sofroniew, M., van Lohuizen, M., et al. 1994. Posterior transformation, neurological abnormalities, and severe hematopoietic defects in mice with a targeted deletion of the bmi-1 proto-oncogene. Genes \& Dev. 8: 757769.

Wang, H., Wang, L., Erdjument-Bromage, H., Vidal, M., Tempst, P., Jones, R.S., and Zhang, Y. 2004. Role of histone H2A ubiquitination in Polycomb silencing. Nature 431: 873-878.
Zhong, L., Georgia, S., Tschen, S.I., Nakayama, K., Nakayama, K., and Bhushan, A. 2007. Essential role of Skp2-mediated p27 degradation in growth and adaptive expansion of pancreatic $\beta$ cells. J. Clin. Invest. 117: 2869-2876. 


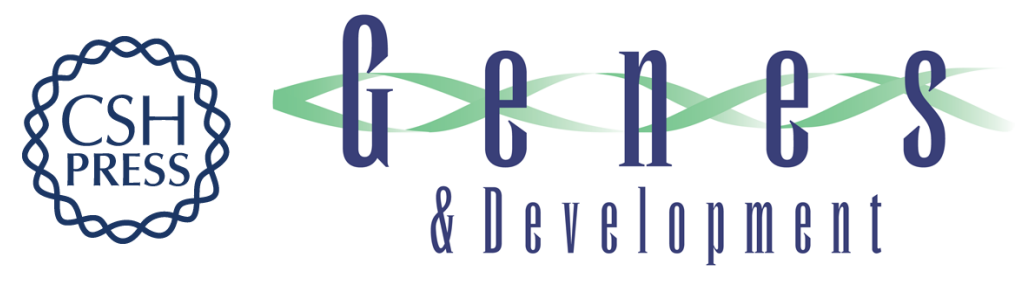

\section{Bmi-1 regulates the Ink4a/Arf locus to control pancreatic $\beta$-cell proliferation}

Sangeeta Dhawan, Shuen-Ing Tschen and Anil Bhushan

Genes Dev. 2009, 23:

Access the most recent version at doi:10.1101/gad.1742609

\section{Supplemental http://genesdev.cshlp.org/content/suppl/2009/04/16/23.8.906.DC1 Material}

References This article cites 25 articles, 9 of which can be accessed free at: http://genesdev.cshlp.org/content/23/8/906.full.html\#ref-list-1

\section{License}

Email Alerting

Receive free email alerts when new articles cite this article - sign up in the box at the top Service 